\title{
Assemblages, episodes and tectonic evolution in the Archaean of China
}

The Archaean continental crust in China mainly occurs within the North China or Sino-Korean Craton. It consists of high-grade metamorphic belts of granulite facies, areas of various amphibolites and intermediate-lower-grade greenstone-granite terrains. The metamorphic assemblages may be divided into four episodes: the Eoarchaean, Paleoarchaean, Mesoarchaean and Neoarchaean.

The granulite belts comprise mainly tonalitic granite gneisses with small amounts of supracrustal rocks or chiefly supracrustal rocks with some granites. The greenstone-granite terrains are mostly of Neoarchaean age. The greenstones are mafic volcanic-sedimentary associations and the mafic volcanics may derive from relatively depleted upper mantle in a rifting environment at a cominental margin. At the end of Archaean, a general plate tectonic regime began, following Late Archaean cratonization of the continental crust in most of the North China Cratom.

All of the rock assemblages mentioned are the products of subduction and collision processes in a plate tectonic model. The cratonic blocks have remained topographically high probably because of vertical thickening with horizonal sheeted piles in the lower crust developing by compressional underplating.

\section{Introduction}

This paper aims to review recent research progress in the Archacan terrains of North China, and to compare them with other well-studied regions in China.

Archaean rock assemblages in China chiefly occur in the north and constitute important tectonic units of the North China Craton (NCC) and the Sino Korcan Craton (SKC). Other Archaean terrains are also found in China but they are smaller in area than the NCC. The rock assemblages, ages of geological events, episodes and tectonic evolution found in China are typical of Archacan cratons in other parts of the world.

\section{Episodes}

Archaean terrains in China are commonly subdivided into Upper, Middle and Lower Archaean, but with Lower and Middle often merged owing to shortage of data. Recently, Archaean terrains have been examined in more detail through multidisciplinary studies which have been helped by the rapid accumulation of more-precise ages (Ma et al., 1979; Wang. 1979; Sheng et al., 1984; Sun et al.,
1985; Qian et al.. 1985, 1990; Zong et al., 1983; Shen et al. 1987; Li. 1987: Jahn et al.. 1984, 1987: Huang et al., 1986; Liu et al. 1990, 1992: Zhong et al., 1992. Song et al., 1993; Nutman et al., 1992: Wu et al., 1990, 1993). Now, it is possible to subdivide the Archacan of China on the basis of new geological data and systematic isotopic age data. Except for assigning $2.6 \mathrm{Ga}$ to the boundary between the Neoarchaean and the Mesoarchaean. we follow the scheme suggested by the International Subcommision on Precambrian Stratigraphy.

\section{Eoarchaean (>3.6 Ga)}

The typical geological unit is the Baijiafen trondhiemitic mylonite (including the Lishan granitic terrain) in Anshan, Liaoning Province. Although exposed in only a small area, it has important geological significance. Single zircons from the intrusive, analysed by means of the sensitive, high-resolution ion microprobe (SHRIMP), yielded an age of $3.8 \mathrm{Ga}$ Supracrustal sequences with radiometric ages greater than 3.8 Ga have not been recorded so far.

\section{Palaeoarchaean (3.6 Ga-3.2 Ga)}

There are two examples of Palaeoarchaean terrains. The first comprises the Chentaigou supracrustal rocks in Anshan, Liaoning

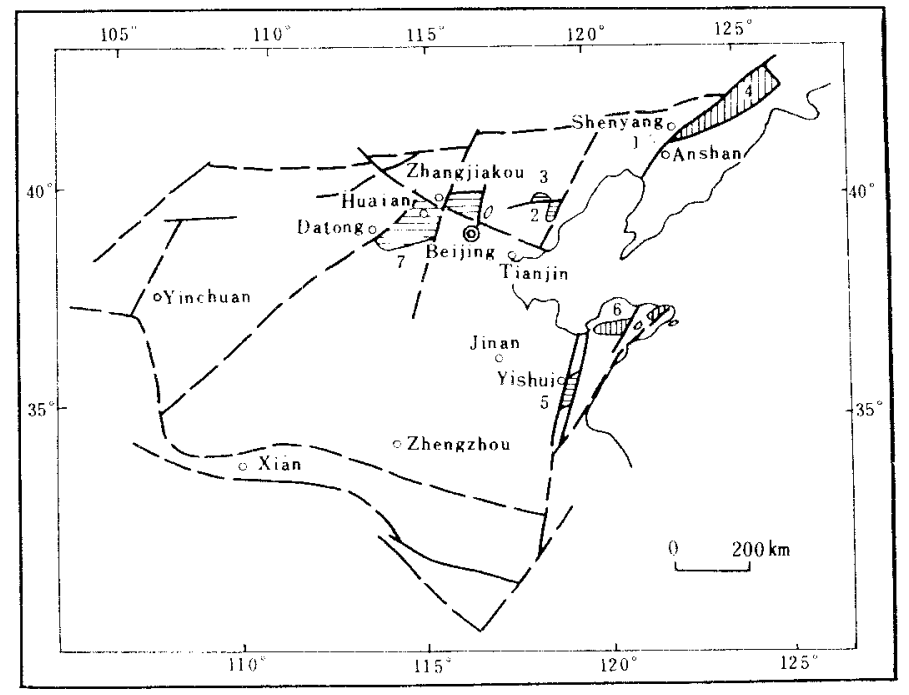

Figure I Geological sketch map showing the distribution of Eoarchean and Mesoarchean terrains in the North China Craton (Modified from Wu et al., 1991).

Legend: horizontal lines: granulite-facies metamorphic terrain; vertical lines: upper amphibolite and local granulite-facies metamorphic terrain; I Anshan region, Liaoning Province (including Bajiafen, Chentaigou and Tiejiashan areas); 2 area of Caozhuang Formation, Qian'an, east Hebei Province; 3 area of Qian'an Complex, east Hebei Province. 4 Huadian-Longgang area, south Jilin Province; 5 area of Yishui Group, in Yishui, Shangdong Province; 6 Jiaodong Group, east Shangdong Province; 7 Huai an-Xuanhua area, north-west Hebei Province. 
Province. It contains amphibolites, hornblende schists, quartzites and biotite leucoleptynites, etc., and is intruded by granite $(3.3 \mathrm{Ga}$ ) (Wu et al., 1993). The second is the Caozhuang Formation (sometimes named the Caozhuang Group or rock assemblages in Qian'an, East Hebei). At Huangbaiyu village, close to Caozhuang, the lower part of the section is chiefly amphibolites, which are followed by fuchsitic quartzite in the middle part, and then by biotite-plagioclase gneisses and anorthositic diopsidites with thin interbeds of impure marble etc. This formation is surrounded by grey gneisses (Wu et al., 1991). The amphibolites from the formation, which was intruded by tonalite $(3.3 \mathrm{Ga})$ and potassic granite $(2.5 \mathrm{Ga})$, yield a Sm-Nd whole rock isochron age of $3.5 \mathrm{Ga}$, (Jahn et al., 1983, 1987: Wang, 1986; Qiao et al., 1990)

\section{Mesoarchaean (3.2 Ga-2.8 Ga)}

Mesoarchaean rocks, which preserve little evidence relevant to the Palaeoarchaean complex, are more extensive than the Eoarchaean and Palaeoarchaean in China. The following examples may be cited:

1 The Tiejiashan granite (3.2-2.9 Ga) and some associated inclusions of supracrustal sequences intruded by the granite in Anshan, Liaoning Province.

2 The Qian an Complex intruded by sheet-like potassic yranite layers $(2.96 \mathrm{Ga}$ ) in east Hebei Province.

3 The Jiaodong Group intruded by granitoids (2.89 Ga) in east Shangdong Province.

4 The Yishui Complex (with a Sm-Nd whole rock age of $2.99 \mathrm{Ga}$ ) in the Yishui region. Shandong Province.

5 Tonalitic gneiss in the Huadian and Longgang area, south Jilin province, (with $\mathrm{Rb}$-Sr whole rock ages of $3.105 \mathrm{Ga}$, [Huhaiqin et al. ]: and $2.97 \mathrm{l} \pm 0.095 \mathrm{Ga}$, / Wujiahongl: $\mathrm{Pb}-\mathrm{Pb}$ ages of 2.95 $\mathrm{Ga}$, [Wangsongshan et al.]; ${ }^{40} \mathrm{Ar}-{ }^{39} \mathrm{Ar}$ ages of $2.989 \pm 0.002 \mathrm{Ga}$, [Wangsongshan et al.]),. The gneiss yielded zircon $\mathrm{U}-\mathrm{Pb}$ and whole rock ${ }^{207} \mathrm{~Pb}-{ }^{206} \mathrm{~Pb}$ ages of $>3.0 \mathrm{Ga}$ with large uncertainty However, Sm-Nd whole rock ages of basic granulites were dated at only $2.426 \pm 0.094 \mathrm{Gu}$.

Although more-precise dating is needed, these data do allow the proposition that there is an older crust in the area.

\section{Neoarchaean $(2.8-2.6 \mathrm{Ga})$}

The Neoarchaean complex is most extensive in the NCC, and also in minor volumes in the Tarim and Jiamus blocks, for example, the Anshan Group (2.75Ga-2.60 Ga), in Liaoning Province, Fuping Group (with a Sm-Nd whole rock age of $2.695 \mathrm{Ga}$ ) in west Hebei Province, Taishan Group in west Shangdong Province $(2.692 \pm 0.118 \mathrm{Ga}, 2.740 \mathrm{Ga})$, Taihua Group $(2.549 \pm 0.169 \mathrm{Ga})$ in Shaanxi and Henan Province, Luanxian Group (2.6 Ga) in east Hebei Province, Jiapigou Group ( $\mathrm{Pb}-\mathrm{Pb}$ age of $2.565 \mathrm{Ga}$ ) in Jilin Province and Fengzhen Group khondalites in Inner Mongolia and north Shanxi Province.

It has been proved that the Anshan Group unconformably overlies the Tiejiashan Granite (2.80-2.97 Ga) (Wu et al., 1993), and the Fengzhen Group khondalites on the basement of the Gehuyao Grey Gneiss Complex (Qian et al., 1992). These facts support the view that the age of the boundary between the Neoarchaean and the Mesoarchaean should be at $2.8 \mathrm{Ga}$

\section{Metamorphic terrains}

\section{Granulite-facies belts (GFB)}

\section{Distribution and division of metamorphic facies types}

Within the NCC, four GFBs are identified (Shen et al., 1992):

- The Inner Mongolia-East Hebei GFB (Qian et al., 1985);

- The Xiaoqinling GFB (Minor Qinling in Shaanxi Province);
- The Lushan (including Wuyang in Henan Province) granulite to amphibolite facies belts (GAFB):

- The Tongbai (in Henan Province) and Dabieshan (in Hubei and Anhui provinces) GAFBs and GAFBs within or east of the

Tancheng-Lujiang fault zone along eastern margin of the NCC. Among these, the Inner Mongolia-East Hebei GFB is the largest. measuring about $1000 \mathrm{~km}$ in an $\mathrm{E}-\mathrm{W}$ direction. It consists of terrains of different ages and with complicated tectonic features, involved multiphase plutonism, and granulite-facies metamorphism, which was followed by amphibolite-facies metamorphism. It has important consequence for the evolution of the NCC.

There are four types of granulite-facies metamorphism. The first is a regional, high-temperature granulite-facies metamophism. which occurred on a large regional scale, and may be further subdivided into two subtypes. The second is medium- to high-temperature regional metamorphism dominated by amphibolite and locally, granulite facies. The third is a regional dynamic heat-flow metamorphism of granulite facies, occurring along linear belts. The fourth is local high-temperature granulite-facies metamorphism associated with dyke-like bodies.

\section{Rock assemblages and protoliths of the granulite-facies bel}

Major rock assemblages include the following types:

I Ultramafic, mafic, intermediate felsic granulites \pm various gneisses \pm plutons (charnockites and trondhjemite - tonalite granodiorite (TTG|). Typically, TTG plutons are dominant in the middle sector of the granulite-facies belt along the north margin of the NCC, in Yanggao-Huai an area, NW Hebei Province.

2 Mafic, intermediate intermediate-felsic granulites \pm various gneisses \pm banded iron formation (BIF) \pm plutonic gneisses (TTG), for example, the eastern sector of the granulite facies belt along the northern margin of the NCC in the QianxiQian'an area, cast Hebei Province.

3 Mafic granulites \pm amphibolite \pm hiotite-plagioclase gneiss. such as the lower subgroup of the Fuping Group in Fuping, west Hebei Province.

4 Aluminum-rich (graphite-bearing) gneisses \pm leucoleptynites \pm quartzites \pm marbles \pm charnockites, which are typical assemblages of the Fengzhen Group extensively distributed over the northern Shanxi Province, southern Inner Mongolia.

The protoliths of the granulite-facies belt may be roughly divided into two types, the first is chiefly Palacoarchaean to Mesoarchaean metavolcanic-metasediments, sometimes with metaplutons (mainly TTG). The second is dominantly Neoarchaean to Mesoproterozoic metasediments, sometimes with metaplutons. In addition, multiple intrusions of mafic dyke swarms are common. Mafic, to intermediate mafic granulites have uniformly positive values of $\epsilon \mathrm{Nd}$ (between 0.5 and 4)). With the exception of the minor rocks, their REE distribution patterns display enrichment in LREEs, suggesting derivation from depleted mantle, although degree of depletion varies.

\section{$P-T$ conditions for the peak of granulite-facies metamorphism}

Present data show that $\mathrm{P}-\mathrm{T}$ values at the peak of granulite metamorphism were roughly in the ranges $750-850^{\circ} \mathrm{C}$, and $0.7-1.0 \mathrm{GPa}$, equivalent to medium-pressure metamorphism. However, the original exogenetic sedimentary rocks in the granulite-facies belt consisting of aluminum-rich gneisses etc., underwent lower-pressure metamorphism. Recently, the mineral associations of Grt+Opx+Qtz of early generation, corresponding to a pressure $1.4 \mathrm{GPa}$, were found within garnet crystals from mafic granulites in the mid to west sector of Inner Mongolia-East Hebei granulite belt along the northern margin of the NCC, in the Huai an area, NW Hebei Province (Zhai et al., 1993). They represent lowermost crust exhumed by continental collision. 


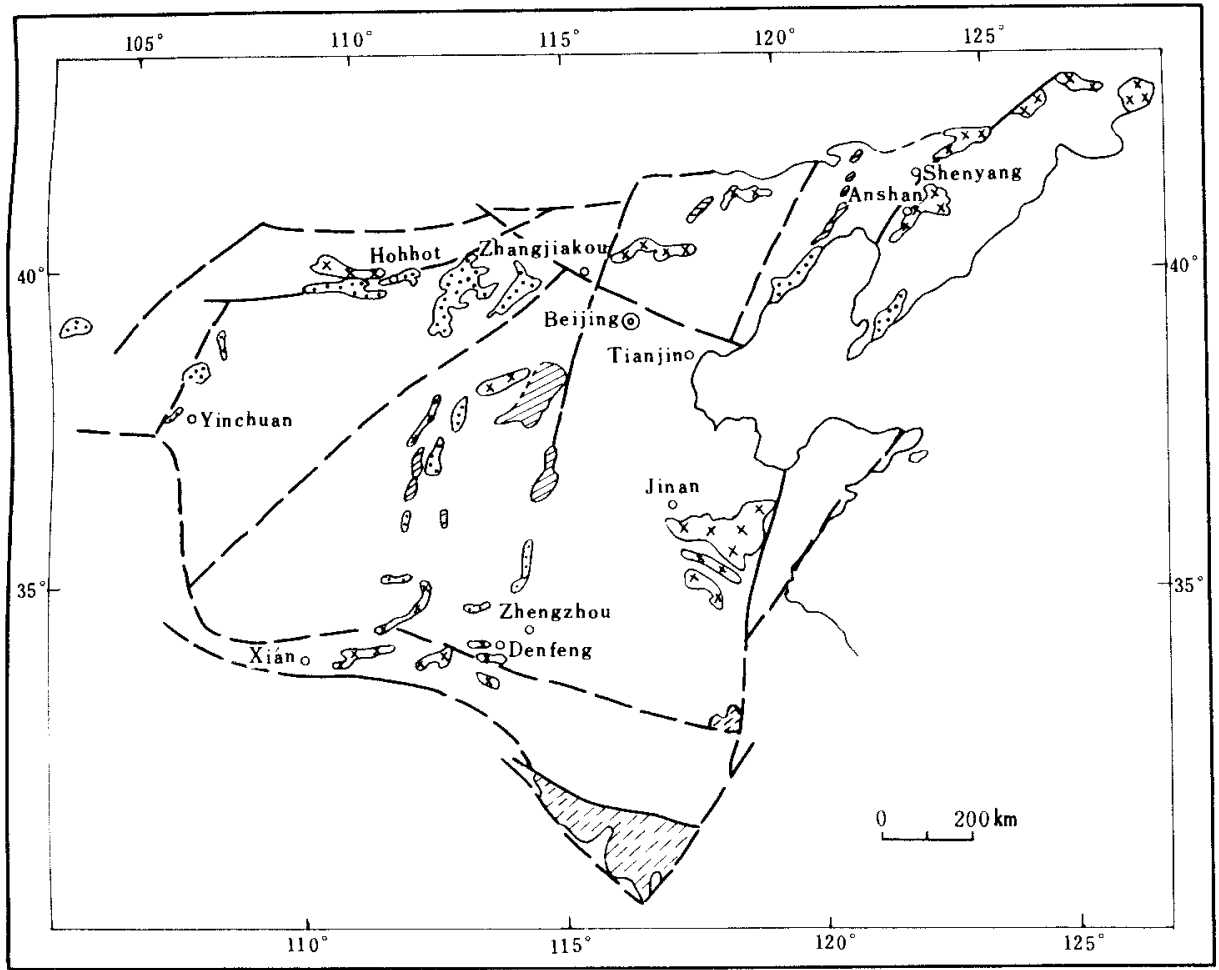

Figure 2 Sketch map showing the distribution of Neoarchaean terrains (Modified after Wu et al., 1991, and Shen et al., 1993).

Legend:

1 crosses: greenstone-granite terrain of greenschist-amphibolite facies; 2 heavy dots: granites of high-grade metamorphic region; 3 fine dots: granulite-facies metasediments; 4 oblique lines: mainly amphibolitefacies metasediments; 5 pecked lines: Neoarchaean and Palaeoproterozoic amphibolite-facies terrains.

\section{Greenstone-granite terrains}

Although greenstone is still a subject of debate among Chinese geologists. the greenstone belts are commonly thought to have been formed mainly in the Neoarchaean and possibly Palaeoproterozoic. They are mostly located along the northern and southern margins of the NCC and are chiefly composed of a suite of mafic volcanics interbeded with ultramafic rocks, andesitic to felsic volcano-sedimentary rocks with interbeds of BIF. They form irregular layers or megabands within regional granitoids. Komatiites with spinifex textures are probably identified from ultramafic rocks of the Taishan Group of high greenschist- to low amphibolite-facies metamorphism, in Xintai, Shangdong Province, which experienced multiphase deformation and was locally imprinted by thermometamorphism. In some cases, it has been confirmed that the greenstone belts unconformably overly the granitic gneiss basement (Wu, 1993; Li et al., 1994).

The REE distribution patterns of the mafic volcanics in the greenstones are characterized by enrichment of LREEs. Mafic rocks from Qingyuan (in Liaoning Province), Dengfeng (in Henan Province) and Luxi (west Shangdong in Shangdong Province), have positive values of e $\mathrm{Nd}(2.23-2.91)$, indicating a source in depleted mantle. It is inferred that the greenstone belts were generated within a tectonic setting such as rifting along the continental margin equivalent to some modern island arcs. Some may have developed in backarc basins at continental margin (Wu et al., 1992, Shen, 1993).

Compared with typical greenstone belts in other parts of the world. those of China have some distinguishing features. Firstly they often have incomplete stratigraphic sequences, and are commonly small in size within limited distribution areas. Ultramafic rocks are especially rare and most lack spinifex textures. Secondly, the metamorphic grade of the belts in China is relatively high, up to high greenschist to low amphibolite facies. Thirdly, after being generated, the greenstone belts were intensely reworked during regional metamorphism and deformation of the unstable crust. Finally, the mineralization of greenstone belts is also distinct and there is a dearth of the $\mathrm{Cu}-\mathrm{Ni}$ deposits generally associated with ultramafic rocks.

\section{Tectonic evolution}

The tectonic evolution of the NCC was very similar to that in most of the world's Archaen cratons. As mentioned before, the oldest zircon ages (greater than $3.6 \mathrm{Ga}$ ) are in granitic rocks, while, the Palaeo- and Meso-archaean terrains in the NCC are also composed mainly of tonalitic granitoids, generated by multistage intrusion of TTG plutons. In addition, there are widely distributed, highly metamorphosed and intensely deformed mafic dyke swarms.

The regional tectonic characteristics show that cratonization took place in the late Archaean and was controlled by an identifiable tectonothermal event, which is of great significance in the evolution history. A sedimentary cover unconformably overlies large areas of the strongly deformed and metamorphosed basement complex. In north Shanxi and Inner Mongolia, these sedimentary cover sequences are $\mathrm{Al}$ rich, but have been converted in the Archaean into granulite-facies khondalites (the Fengzhen Group). In the region from Datong to Xinghe, the stratigraphic unconformity indicates late Archaean cratonization. In the southern part of the NCC, in west Henan Province, the Taihua Group probably also unconformably overlies the grey gneiss complex as late Archaean sedimentary cover of the Fengzhen Group. This important event has a probable age range of $2.8-2.6 \mathrm{Ga}$. In a set of $198 \mathrm{Sm}-\mathrm{Nd}$ model age determinations, $82.3 \%$ of the results are within the range $3.0-2.5 \mathrm{Ga}$ with two clusters at 2.9 and $2.7 \mathrm{Ga}$. (Zhang, personal communication). These two ages may indicate two periods of cratonisation but it is more reasonable to interpret them as indicating one late Archaean tectonothermal event.

In the Archaean, the values of $\varepsilon \mathrm{Nd}(\mathrm{T})$ decreased gradually with younger $\mathrm{T}_{\mathrm{DM}}$. This indicates that a crustal component was incorporated into these rocks. Archaean metamafic rocks of the NCC have lower $\mathrm{Nd}$ contents, and various ratios of $\mathrm{La} / \mathrm{Nb}$, which reveal that there are significant crustal components (Jahn, 1990). Negative $\mathrm{Nb}$ anomalies are characteristic of the mafic granulites within the granulite-facies belt along the northern margin of the NCC. Their chondrite-normalised trace element distribution patterns are very similar 
to those of mafic volcanics from modern island ares, continental margins, and continental basalts contaminated with continental crust. (Shen et al., 1992)

The earliest late-Archaean craton in China is very extensive, and became a rigid, principle tectonic unit. The geothermal gradient during the Archaean granulite-facies metamorphism ranged from $25^{\circ}-30^{\circ} \mathrm{C} / \mathrm{km}$ (measured by geothermobarometers in Inner Mongolia-East Hebei granulite belt). This range resembles very much the geothermal gradient of the present cratonic crust. The late Archaean NCC was surrounded by several sets of boundary faults indicating fragmentation of the previous Archaean craton in the early Proterozoic, and the development of an aulacogen system. Greenstones developed in rifts within the fragmanted cratonic region.

It is worthwhile to emphasize that the Inner Mongolia-East Hebei granulite-facies belt was formed by continental collision in a plate tectonic regime at the end of Archaean. It was subsequently unconformably overlain by the Palaeoproterozoic Wutai greenstone sequences (Qian et al., 1985). The topographically high position of the old cratonic blocks, which have been subject denudation throughout their long history, may be related to the fact that the lower continental crust has experienced thicking by compressional underplating by sheeted piles (Qian et al., 1985; Qian, 1992, 1994; Wu et al., 1991; Zhao et al.,1993).

\section{References}

Bai, J, 1986, The early Precambrian geology of Wutaishan, Tianjin: Science and Technology Press, Tianjin, $435 \mathrm{pp}$.

Bai, J, Li, H M, and Wang, R Z, 1991, U-Pb single zircon isotope ages for the Wutai granite-greenstone and their possible geological significance: $B u l-$ letin Tianjin Institute of Geology and Mineral Resources, no. 25, pp $1-12$.

Cheng. Y Q, Sun, D Z, and Wu, J S, 1984, Evolutionary megacycles of the carly Precambrian proto-North China platform: Journal of Geodynamies, no. 1. pp. 251-277.

Chung, F T, Compston, W, Foster, J, and Sun, D Z, 1979, Age of the Chien Group: North China Research School of Earth Science. Annual Report. The Australian National University, pp. 147-159.

Compston, W, Chung, F T, Foster, J, Collerson, K D, Bai, J, and Sun, D 7, 1983, Rubidium strontium geochronology of Precambrian rocks from the Yenshan region, North China: Precambrian Research, v. 22, pp. 175-202.

Condie, K C. Boryta, M D, Liu, J Z and Qian, Xianglin. 1992, The origin of khondalites: geochemical cvidence from the Archaean to early Proterozoic granulite belt in the North China Craton: Precambrian Research, v. 59, pp. 207-223

Cui, W Y, Wang, S Q, Wei, C J, and Tao, Q, 1989, Characteristics and evolution of the lower Precambrian basement of the North China platform: Journal of Southeast Asian Earth Sciences, v. 3, pp.283-291.

Cui, W Y, Wang, C Q, Sun, C Z, and Zhang, Y, 1991, The zircon U-Pb ages of Archaean metamorphic rocks in western Liaoning Province Chifeng area: Acta Scientium Naturalium, Universitis Pekinesis, v. 27, no.2, pp. $229-237$

Guo, Anlin, 1988, Relationships between the TTG gneisses and the greenstone belt in the Archaean Dengfeng granite-greenstone terrain, Central Henan and their implications for crustal evolution: Geological Review, v. 34, no. 2 , pp. 123-131

Huang, X, Bi, Z, and DePaolo, D J, 1986, Sm-Nd isotope study of early Archaean rocks, Qian'an, Hebei Province, China: Geochimica et Cosmochimica Acta, v. 50, pp.625-639

Jahn. B M, and Zhang, Z Q, 1984, Radiometric ages (Rb-Sr, Sm-Nd, U-Pb) and geochemistry of Archaean granulite gneisses from eastern Hebei Province, China, in Kroner, A, Hanson, G, and Goodwin, A M, eds., Archaean Geochemistry: Springer-Verlag, pp.204-234.

Jahn, B M, and Zhang, Z Q, 1984, Archaean granulite gneisses from eastern Hebei Province, China: rare earth geochemistry and tectonic implications: Contributions to Mineral and Petrology, v. 85, pp.224-243.

Jahn, B M, Aurvay B, Cornichet, J, Bai, Y L, Shen, Q H, and Liu, D Y, 1987, $3500 \mathrm{Ma}$ old amphibolites from eastern Hebei Province, China: field occurrence, petrography, $\mathrm{Sm}-\mathrm{Nd}$ isochron age and REE geochemistry: Precambrian Research, v. 34, pp.311-346.

Jahn, B M, Aurvay, B, Shen, Q H, Liu, D Y, Zhang, Z Q. Dong, X J, Yeh, X J, 1988, Archaean crustal evolution in China: the Taishan Complex and evidence for juvenilc crustal addition from long-term depleted mantle: Precambrian Research, v. 38, pp.381-403.

Jahn, B M, 1990, Origin of granulites: geochemical constraints from Archacan granulites facies rocks of the Sino-Korean Craton, China, in Vielzeuf, D, and Vidal, P, eds., Granulites and crustal evolution: Kluwer Acadernic Publishers, Netherlands, pp.471-492.

Jahn, B M, 1990, Early Precambrian basic rocks of China, in Hole, R P, and Hughes, D J, eds., Early Precambrian basic magmatism: Blackic. pp. 294-316.

Kroner, A, Compston, W, Zhang, G W, Guo, A L, and Tolt, W, 1988, Age and tectonic setting of Late Archaean greenstone gneiss terrain in Henan Province, China, as revealed by single grain zircon dating: Geology, v. 16, pp.211-215.

Li, J H, and Qian, X L, 1994, The Early Precambrian crustal evolution of Hengshan Metamorphic Terrain, North China Craton: Shanxi Science and Technology Press, Taiyuan.

$\mathrm{Li}, \mathrm{S} \mathrm{G}$, and Zhang, Z Q, 1990, Nd isotopic composition and evolution of the upper mantle in the Archacan of North China: constraints on the mantlc heterogeneity of the unmetasomatic continental lithosphere: Geochimica no. 4, pp. $277-285$.

$\mathrm{Li}, \mathrm{S} \mathrm{G}$, Hart, S R, and Wu, T S, 1990, Rb-Sr and Sm-Nd isotopic dating of an carly Precambrian spilite-kerotophyre sequence in the Wutaishan area, North China: preliminary evidence for Nd-isotopic homogenization in the matic and feisic lavas during low-grade metamorphism: Precambrian Research, v. 47, pp. 191-203.

Li, S G, Hart, S R, Gaw, A L, and Zhang, G W, 1987, Whole rock Sm-Nd isotopic age and its tectonic significance of Dengfeng Group in middle par of Henan Province: Bulletin of Sciences, 1987, no. 22, pp. 1728-1731.

Liu, D Y, Page, K W, Compston, W, and Wu, J S, 1984, U-Pb Zircon geochronology of Precambrian metamorphic rocks in the Taihangshan-Wutaishan area, North China: Bulletin of the Chinese Academy of Geological Sciences, no. 8, pp.57-81

Liu. D Y. Shen, Q H, Zhang, Z Q, Jahn, B M, and Aurvay, B, 1990, Archaean crustal evolution in China: U-Pb geochronology of the Qianxi Complex. Precambrian Research, v. 48, pp.223-244.

Liu, D Y, Nutman, A P, Compston, W, Wu, J S. and Shen, Q H, 1992, Remnants of $\geqslant 3800$ Ma crust in the Chinese part of the Sino-Korean Craton Geology, v. 20, pp.339-342.

Ma, X Y, and Wu, Z Y, 1981, Early tectonic cvolution of China: Precambrian Research, v. 14, 185-202.

Nutman, A, Liu, D Y, Wu, J S, and Song, B, 1993, 3800Ma-2500Ma crustal cvolution in the Anshan Complex, Anshan, Liaoning Province, NE China: Field excursion report, IGCP project 280 Symposium, 1993. pp. 1-24.

Plumb, K A, and Jamer, H L, 1986, Subdivisions of Precambrian Time: recommodations and suggestions by the Subcommision on Precambrian Stratigraphy: Precambrian Research, v. 32, pp.65-92.

Qian, X L. Cui,W, and Wang, S, 1985, Evolution of the Inner Mongolia-Eastern Hebei Archaean granulite belt in the North China Cralion, in Records on geological research at Peking University: Publishing House of Peking University, Beijing, pp.20-29.

Qian, X L, Chen, Y P, and Liu, J Z, 1987, Archaean crustal evolution of the North China Craton: Workshop on the Growth of Continental Crust. Oxford, England, July 13-16, 1987, Abstr, pp.76-78.

Qian, X L, 1992, Archaean cratonization in the northern China, collage of terranes and model of plate tectonic movement, in Proccedings of 70 th Anniversary of Founding the Geological Society of China: Beijing Science and Technology Press, pp.93-97.

Qian, X L, 1994, A tectonic model of the intraplate thickening of continental crust. Proceedings of Continental Extensional Tectonics: Geological Publishing House. Beijing, pp.32-36.

Qiao, G S, Wang, K Y, Guo, A.F, and Zhang, G T, 1987, Sm-Nd dating of Caozhuang early Archaean supracrustal, eastern Hebei: Scientia Geologica Sinica, no.1, pp.86-92.

Qiao, G S, Zhai, M G, and Yan, Y H, 1990, Geochronological study of Anshan-Benxi Archaean metamorphic rocks: Scientia Geologica Sinica, no. 2, pp. $158-165$.

Shen, B F, Peng, X L, Luo, H, and Mao, D B, 1993, Archaean greenstone belts in China: Acta Geologica Sinica, v. 67, no. 3, pp.208-220.

Shen, Q H, Liu, D Y, Wang, P, Guo, J F. and Zhang, Y.F, 1987, U-Pb and Rb Sr isotopic age study of the Jining Group from Nel Mongol of China: Bulletin of the Chinese Academy of Geological Sciences, no. 16, pp. $165-178$

Shen, Q H, Xu, H F, Zhang, Z Q, Gao, J F and Ji, C L, 1992, Early Precam brian granulites of China: Geological Publishing House, Beijing. 
Shen, Q H, Zhang, Y F, Gao, J F. and Wang, P, 1989, Archaean metamorphic rocks in mid-southern part of Nei Mongol: Bulletin of the Institute of Geology, Chinese Academy of Geological Sciences, no. 21, pp.19-29.

Sills, T D, Wang, K Y, Yan, Y H, and Windley, B F, 1987, The Archaean high-grade gneiss terrain in E Hebei Province, NE China: Geological framework and condition of metamorphism, in Park, R G, and Tarney, J, eds., Evolution of the Lewisian and comparable Precambrian high-grade terrain: Geological Society Special Publication, London, no. 27, pp. 279-305.

Sun, M, Armstrong, R L, and Lambert, R St J, 1992, Petrochemistry and Sr. $\mathrm{Pb}$ and $\mathrm{Nd}$ isotopic geochemistry of early Precambrian rocks, Wutaishan and Taihangshan areas, China. Precambrian Research, v. 56, pp.1-31.

Wang, Q C, 1988. The stratigraphical, division and correlation of the early Precambrian in the Taihang-Wutai area, the Yanshan area and the eastern sector of the Yinshan Mountains: Acta Geologica Sinica, no. 1, pp.16-30.

Wang, $\mathrm{HZ}, 1986$ Precambrian geochronologic and chronostratigraphic subdivision of China: Earth Science Journal of Wuhan College of Geology, v. 11 , no. 5 , pp. $447-453$.

Wang, S S, Zhai, M G, Hu, S L, Sang, H Q, and Qiu, J, 1986, ${ }^{40} \mathrm{Ar} /{ }^{39} \mathrm{Ar}$ age spectrum for biotite separated from Qingyuan tonalite, NE China: Scientia Geologica Sinica, no. 1, pp.97-100.

Wang, S S, Hu, S L, Zhai, M G, Sang, H Q, and Qiu J, 1987, An application of the ${ }^{40} \mathrm{Ar} /{ }^{39} \mathrm{Ar}$ dating technique to the formation time of Qingyuan granite-greenstone terrain in NE China: Acta Petrologica Sinica, v. 4, no. 4. pp.55-62.

Wang, K, Windley, B F, Sills, J D, and Yan, Y, 1990, The Archaean gneiss complex in E. Hebei Province, North China: Geochemistry and evolution: Precambrian Research, v. 48, pp. 245-265.

Wu, J S, Geng, Y S, Shen, Q H, Liu, D Y, Li, Z L, and Zhao, D M, 1992, Major geological events of early Precambrian in North China platform: Geological Publishing House, Beijing.

Wu, J S, and Wan, Y S, 1993, Formation and evolution of the Archaean crust in Anshan, Liaoning Province (abstract): Field Excursion of the IGCP Project 280 Symposium, 1993, pp.1-4.

Zhai, M G, Guo, J H Yan, Y H, Han, X L, and Li, Y G, 1992, High pressure basic granulite and disclosing of a lowermost crust of the early Archaean continental type in N. China: Advances in Geoscience (2), Institute of Geology Sinica: China Ocean Press, Beijing, pp.126-139.

Zhang, Z Q, Wu, J S, and Ye, X J, 1991, Archaean metamorphic rocks from the lower Fuping Group in the Mt. Taihang region, North China: REE geochemistry, Rb-Sr and Sm-Nd ages and implications. Geochemica, no. 2. pp. $118-127$.

Zhao, Z P, 1988, Subdivision of Precambrian time and rock, stratigraphic units of eastern China: inference from Precambrian crustal evolution of eastern Hebei Province: Scientia Geologica Sinica, no. 4, pp.301-312.
Zhao, Z P, et al, 1993, The Precambrian geological evolution of Sino-Korean paraplatform: Science Publishing House, Beijing.

Zhong, F D, 1984, Geochronological study of Archaean granite gneisses in Anshan area, Northeast China. Geochemica, no. 3, pp. 195-205.

Qihan Shen was born in 1922. He is a Research Fellow at the Institute of Geology, Chinese Academy of Geological Sciences; a member of the Academia Sinica; a standing member of the Society of Minerology, Petrology and Geochemistry of China; Chairman of the Commission on Metamorphic Petrology; member of the Editorial Board of Science in China, and Editor-in-Chief of the Journal of Petrology-Minerology. He has undertaken research in metamorphic petrology, early Precambrian geology and isotope geochronology.

Xianglin Qian, born in 1929, is Professor of Geology at Peking University; Vice Chairman of Commission on Tectonics of China and Director of the Department of Earth Science, National Natural Science Foundation of China. He is interested in structural geology and tectonics, especially the early evolution of the continental crust in the North China Craton. He participated in IGCP 92 (Archaean Geochemistry) and IGCP 257 (Mafic Dyke Swarms). He is a Member of the Editorial Board of Acta Geologia Sinica and of Science in China. His current research activities also include the tectonic evaluation of petroleum geology in China.
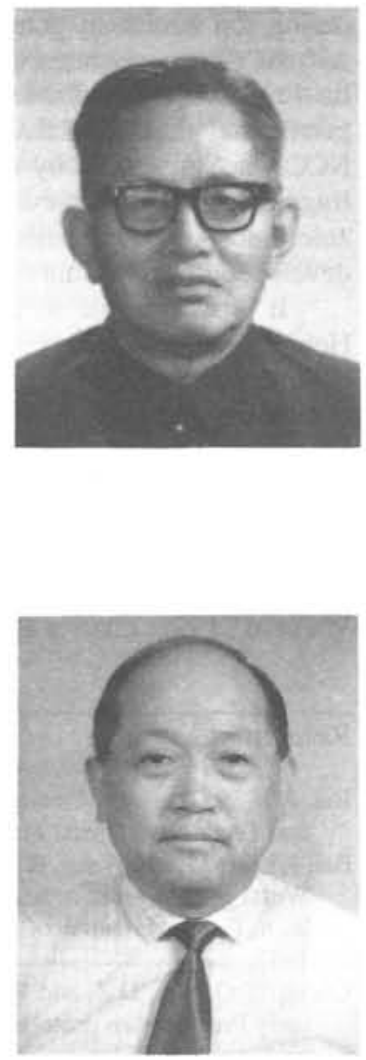